$10-1-2001$

\title{
Race to the Stars: A Federalism Argument for Leaving the Right of Publicity in the Hands of the States
}

\author{
Usha Rodrigues \\ University of Georgia School of Law, rodrig@uga.edu
}

P

\section{Repository Citation}

Usha Rodrigues, Race to the Stars: A Federalism Argument for Leaving the Right of Publicity in the Hands of the States (2001),

Available at: https://digitalcommons.law.uga.edu/fac_artchop/381

This Article is brought to you for free and open access by the Faculty Scholarship at Digital Commons @ University of Georgia School of Law. It has been accepted for inclusion in Scholarly Works by an authorized administrator of Digital Commons @ University of Georgia School of Law. Please share how you have benefited from this access For more information, please contact tstriepe@uga.edu. 


\title{
RACE TO THE STARS: A FEDERALISM ARGUMENT FOR LEAVING THE RIGHT OF PUBLICITY IN THE HANDS OF THE STATES
}

\author{
Usha Rodrigues*
}

\section{INTRODUCTION}

7 HIS Note will argue that, given the variation in the right of 1 publicity from state to state, and the relative newness of this property right, Congress should refrain from passing a law to federalize it.' Although there are sound arguments for adopting this right, there are also reasons to hesitate. Given that only half of the states have adopted it, federalization seems premature. This Note will only obliquely address the main objection usually leveled at a robust right of publicity, namely that it stifles creativity and implicates First Amendment concerns. The focus instead will be on the right of individual states to choose not to create this property riglit within their borders, and the workability of a state-based system where rights of publicity are not uniform.

- The author would like to thank Professor Thomas W. Merrill for his help and guidance with this Note.

'A Joint Task Force of members of different committees of the Intellectual Property Section of the American Bar Association has advocated a federal right of publicity statute and drafted a model statute. The Section as a whole adopted a resolution supporting a federal approach. Right of Publicity, 1994-1995 A.B.A. Sec. Intell. Prop. L. Ann. Rep. 212, 212-15; Right of Publicity, 1995-1996 A.B.A. Sec. Intell. Prop. L. Ann. Rep. 202, 250; see also Symposium, Rights of Publicity: An InDepth Analysis of the New Legislative Proposals to Congress, 16 Cardozo Arts \& Ent. L.J. 209 (1998) (panel discussion). In addition, many scholars have advocated adopting federal right of publicity legislation to solve the problems created by a statebased regime. See, e.g, Eric J. Goodman, A National Identity Crisis: The Need for a Federal Right of Publicity Statute, 9 DePaul-LCA J. Art \& Ent. L. 227 (1999); Alice Haemmerli. Whose Who? The Case for a Kantian Right of Publicity, 49 Duke L.J. 383 (1999): Richard Masur, Right of Publicity From the Performer's Point of View, 10 DePaul-LCA J. Art \& Ent. L. 253, 255-58 (2000); Kevin M. Fisher, Comment: Which Path to Follow: A Comparative Perspective on the Right of Publicity, 16 Conn. J. Int'l L. $95,115(2000)$. 
The riglit of publicity is a property right in the commercial use of one's persona. Approximately half of the states recognize it. ${ }^{2}$ Some of these make it descendible and assignable; in others, it expires witli death. Although publicity rights are conceptually related to privacy rights, an area of tort law, the publicity right itself is a property right in the elements of personal identity. Privacy is a more limited riglit, which usually protects names and likenesses only. ${ }^{4}$ Privacy is a personal right that cannot be sold or given away, and lasts only through a person's lifetime. Publicity, m contrast, is alienable, may survive death, and has been expanded to protect a person's voice, gestures, and inannerisms. ${ }^{5}$

The right of publicity occupies a somewhat liminal position in the law. It is a property right, with the attendant characteristics of alienability and, sometimes, lieritability. Like most property rights, it is state-created. But unlike inost real property rights, its value is connected with persons, and is therefore mobile. Celebrities have received the ability to sue for commercial nnisappropriation even when they cannot claim more traditional privacy rights, but the cost of this creation of property rights has been uncertainty as to low far these rights extend beyond the borders of a given state and as to which state's laws govern a particular misappropriation.

As celebrities seek out more protection against commercial exploitation, the right of publicity is beconning increasingly important. For example, in cases of digital manipulation, celebrities' personas may be used to promote merchandise without their consent. Action under the Lanham Act ${ }^{6}$ requires that there be consumer confusion, which may not exist in today's age of savvy marketing. There is no copyright clann if the image is not actually copied, but rather recreated and manipulated in cyberspace. Imagine a digital Marilyn Monroe hawking a certain kind of razor. She could gush that, if only she had liad it at the time, the subway scene

${ }^{2}$ See Thomas W. Merrill \& Henry E. Smith, Optimal Standardization in the Law of Property: The Numerous Clausus Principle, 110 Yale L.J. 1, 20 n.78 (2000).

${ }^{3}$ Diane Leenheer Zimmerman, Who Put the Right in the Right of Publicity?, 9 DePaul-LCA J. Art \& Ent. L. 35, 36 (1998).

${ }^{4}$ Id. at 41 n.19.

${ }^{s}$ Id.; see also Restatement (Second) of Torts $\S 652 \mathrm{C}$ (1977) (describing the tort of appropriation of name or likeness).

${ }^{6} 15$ U.S.C. $\$ 1125$ (1994). The Act protects trademarks and service marks that identify and distinguish goods and services. 
in the Seven-Year Itch would have been so much easier to prepare for. Consumers would not actually think that she was endorsing the product, and there would be no original from which the digital Marilyn was "copied." Could or should her heirs or assigns be able to stop this use, because they do not want her image used in this way? Do they have a right to share in the profits from it? States address these questions by constructing various right of publicity regimes.

After tracing the development of the right of publicity, this Note will give a more detailed description of its current form. It will then make a case for federalism in the area of the right of publicity, that is, a case for maintaining the status quo and letting the states define the right for themselves. To prove that states could reasonably disagree as to the merits of a publicity rights regime, this Note will examine the common justifications for the right as well as critical responses to them. However, the choice that states confront is not a simple all-or-nothing one: The fact that the right of publicity varies so widely even among states that recognize it indicates that they are experimenting with regard to various attributes of the right.? This variation leads to conflicts as plaintiffs attempt to protect their personas from exploitation in fora that may not recognize the right. The Note will then present a solution for the most serious practical problem that the current, state-based right of publicity regime faces: choice-of-law conflicts. Finally, it will use the community property system to illustrate how a property regime can successfully vary from state to state.

\section{HISTORY}

Commentators generally trace the development of the right of publicity from the growth in the recognition of a right to privacy in

'In reaction to a Ninth Circuit decision finding for the defendant and protecting the use of footage of Fred Astaire in a dance instruction video, Astaire v. Best Film \& Video Corp., 116 F.3d 1297 (9th Cir. 1997), the Califoruia Legislature passed the Astaire Celebrity Image Protection Act, Cal. Civ. Code $\$ 3344.1$ (West 1999). This act provides that "[a]ny person who uses a deceased personality's name, voice, signature, photograph, or likeness, in any manner, on or in products, inerchandise, or goods, or for purposes of advertising or selling, or soliciting purchases of, products, merchandise, goods or services, without prior consent" is liable for damages. Id. at $\$ 3344.1$ (a)(1). 
this country with the publication of Samuel D. Warren and Louis D. Brandeis's article, "The Right to Privacy." The property-like status of the right of publicity arose as courts grappled with the awkwardness of having to use the right of privacy to award damages to celebrities who deliberately sought the public eye, but whose likenesses had been used without their consent.. For example, in O'Brien v. Pabst Sales Co., ${ }^{10}$ a beer producer used the picture of a college football star on a promotional calendar. ${ }^{11}$ The court concluded that a plaintiff who had exposed himself to the public's eye in such a fashion had no plausible claim for privacy protection and therefore denied his claim. ${ }^{12}$ In Haelan Laboratories v. Topps Chewing Gum, ${ }^{13}$ Judge Jerome Frank solved the problem of protecting celebrities from nonconsensual commercial use by creating a property right in persona. ${ }^{14}$ Judge Frank saw the publicity right as a way to avoid the clumsy logic required whenever public figures complained of an invasion of privacy. ${ }^{15}$

From this pragmatic origin, the right of publicity has grown enormously. ${ }^{16}$ There was a time when personality was protected

${ }^{8}$ Goodman, supra note 1 , at 230,232 ; Samuel D. Warren \& Louis D. Brandeis, The Right to Privacy, 4 Harv. L. Rev. 193 (1890).

${ }^{9}$ Although some states do not limit the right of publicity cause of action to celebrities, in practice only celebrities will usually have damages high enough to warrant undertaking a suit. For the purposes of this Note, I will therefore refer to plaintiffs and potential plaintiffs as celebrities. For an interesting case of a noncelebrity privacy plaintiff, see Roberson v. Rochester Folding Box Co., 64 N.E. 442 (N.Y. 1902).

${ }^{10} 124$ F.2d 167 (5th Cir. 1941).

"Id. at 168.

12 Id. at 170 .

${ }^{13} 202$ F.2d 866 (2d Cir. 1953).

${ }^{14}$ Id. at 868.

${ }^{15}$ Id.

${ }^{16}$ Curiously enough, one could trace much of the history of this growth entirely through baseball card and baseball statistic cases. The right was initially established in a baseball card case, Haelen Laboratories, 202 F.2d 866. It was expanded in Allison $v$. Vintage Sports Plaques, 136 F.3d 1443 (11th Cir. 1998) (holding that resale of cards mounted on plaques is defensible under the first-sale doctrine). Its limits were explored in cases like Cardtoons L.C. v. Major League Baseball Players Ass'n, 95 F.3d 959 (10th Cir. 1996) (finding the parody defense to be available even for commercial use) and Uhlaender v. Henricksen, 316 F. Supp. 1277 (D. Minn. 1970) (holding that the use of players' statistics in a trivia game was a commercial, not mformational, use). For a twist, a recent case involved a major league pitcher's characteristic stance in a Killian's Beer advertisement. Newcombe v. Adolf Coors Co., 157 F.3d 686 (9th Cir. 1998). 
only under privacy, and the harm suffered was presumed to be an invasion of privacy, rather than a deprivation of property. More recently, the right of publicity has expanded in some states into a robust property right that can protect various aspects of identity. ${ }^{17}$

The only Supreme Court case to examine the right of publicity was Zacchini v. Scripps-Howard Broadcasting $\mathrm{Co}^{18}{ }^{18}$ Zacchini sued a local news program that had aired the entire fifteen seconds of his "huinan cannonball" act performed at a county fair. The Court legitimized both the right and the rationales behind it. It articulated two broad reasons why Ohio would seek to protect the right of publicity. First, the right of publicity prevents unjust enrichment; in this case, the riglit served to protect not simply the performer's reputation, but his very effort to gain fame and recognition. ${ }^{19}$ Second, it creates the economic incentive required to motivate performers to engage in this sort of activity, free from the danger that the resulting persona will be appropriated and some of the proceeds diverted for the gain of another. ${ }^{20}$

The Court used the unusual facts of Zacchini's case to expand further the right of publicity to include a broad "performance right" in the publicity of an entertainer's entire performance. ${ }^{21}$ "Zacchini thus signaled that the bundle of property entitlements an entertainer receives under the right of publicity need not be hinited to the 'sticks' labeled name and likeness." ${ }^{22}$ Later state cases have protected a celebrity's mickname ("Crazylegs"), characteristic phrase ("Here's Jolinny"), and characters portrayed by the celebrity ("Spanky" of the Little Rascals, and "Norm" and "Cliff" of Cheers). ${ }^{23}$ While understandable in the case of Zacchini, this move

${ }^{17}$ See Zimmerman, supra note 3 , at 37-38.

in 433 U.S. 562 (1977).

${ }^{14}$ Id. at 576.

2"Id.

"Id. at 575-76. "Moreover, the broadcast of petitioner's entire performance, unlike the unauthorized use of another's name for purposes of trade or the incidental use of a name or picture by the press, goes to the lieart of petitioner's ability to earn a living as an entertainer." Id. at 576. Because of its unusual circumstances, Zacchini's protection of a performance right is a narrow protection. See Zimmerman, supra note 3 , at 50 .

"Arlen W. Langvardt, The Troubling Implications of a Right of Publicity "Wheel" Spun Out of Control, 45 U. Kan. L. Rev. 329, 357 (1997).

${ }^{\prime}$ Id. at 387-93. In the last case, Host International put in its bars aninuatronic figures that plamtiffs George Wendt and John Ratzenberger claimed resembled them. 
to protect various isolatable features of celebrities' likenesses and personas has proved controversial.

"Soundalike" cases, which involve efforts by marketers to use singers who can duplicate the distmctive voices and styles of famous singers, were rejected until the late 1980s. For example, in Lahr v. Adell Chemical Co. ${ }^{24}$ the First Circuit rejected claims of rights of publicity and privacy violations for appropriation of voice. ${ }^{25}$ Nancy Sinatra similarly failed in an attempt to press a pubhicity claim against Goodyear Tires for employing singers who imitated her vocal style. Goodyear had obtained permission from the copyright holders to use the song "These Boots Were Made for Walking."26 By the 1980s, however, Bette Midler and Tom Waits were able to wm on right of publicity grounds in soundalike cases. ${ }^{27}$ The cases turned on whether the imitation was that of a specific recording, which would be governed by federal copyright law, or that of unique voice style, which is an attribute protected under the right of pubhicity, at least in California. Some commentators think that courts have gone too far in this realm, granting celebrities property riglits in attributes that are not umique, but rather common in a large segment of the population. ${ }^{28}$

The case that has stretched the limits of right of publicity protection the furtlest to date is White v. Samsung Electronics America, Inc. $^{29}$ In that case, Samsung advertised the longevity of its video cassette recorders witl the image of a robot in an eveming gown, adorned witl jewelry and a blonde wig, by the Wheel of Fortune set, captioned "Longest-Running Game Show, 2012 A.D." Although some commentators do not believe jewelry, a blonde wig, and an evenimg gown alone should be enough to trigger right of publicity protection, the Ninth Circuit found that the plaintiff, Vanna White, had demonstrated sufficient issues of fact to warrant

The Ninth Circuit refused to take a position on whether the characters "Norm" and "Cliff" could be part of the plaintiffs' identities. Id. at 393 n.412.

${ }^{24} 300$ F.2d 256 (1st Cir. 1962).

${ }^{25}$ Id. at 258.

${ }^{26}$ Sinatra v. Goodyear Tire \& Rubber Co., 435 F.2d 711 (9th Cir. 1970).

${ }^{27}$ See Waits v. Frito-Lay, 978 F.2d 1093 (9th Cir. 1992); Midler v. Ford Motor Co., 849 F.2d 460 (9th Cir. 1988).

${ }^{28}$ See White v. Samsung Elec. Am., 989 F.2d 1512, 1516 (9th Cir. 1993) (Kozinski, J., dissenting). See generally Langvardt, supra note 22.

29971 F.2d 1395 (9th Cir. 1992).

${ }^{30}$ Id. at 1396. 
a jury trial. ${ }^{31}$ Granting property rights in such common attributes could result in a race to the courthouse, as individuals attempt to claim hairstyles or accessories as their personal property and reap the financial rewards that such property rights afford them.

The right of publicity at the present time varies widely from state to state. It is a right created by states, either through statute or common law. Twenty-seven states currently have some form of the right. ${ }^{32}$ Others do not recognize the right at all. Even among states that recognize the right, its parameters differ dramatically. In Florida, publicity rights last forty years after the death of the celebrity. ${ }^{33}$ Kentucky, Texas, and Nevada provide rights that will lapse after fifty years; California's right lapses after seventy years. ${ }^{34}$ In Indiana and Oklahoma the right survives one hundred years after the death of the celebrity. ${ }^{35}$ Finally, Tennessee and Nebraska allow the right to continue indefinitely, although in Tennessee publicity rights will terminate if they are not used for two consecutive years. ${ }^{36}$ Variations also exist in what aspects of persona (for example, voice, gestures, or mannerisms) are protected and in whether the right is assignable or descendible. ${ }^{37}$ Potential remedies for a right of publicity action include injunctions and damages. ${ }^{3 s}$

\section{THE BENEFITS of FEdERALISM IN THE RIGHT OF PUBLICITY CONTEXT}

This Part presents several arguments for retaining the current system of state-based rights of publicity. First, since half of the states have not recognized the right at all, there is no clear resolution that protection of the right of publicity is a benefit. To use the terms current in federalism arguments, the question of whether the

"Id. at 1408.

See Merrill \& Smith, supra note 2, at 20 n.78; Bruce P. Keller \& David H. Bernstein, The Right of Publicity: Towards a Federal Statute?, 532 PLI/Pat 413, 418 n.12 (1998).

"Bruce P. Keller, The Right of Publicity: Past, Present and Future, 808 PLI/Comm $159,181(2000)$.

4 Id.

"Id.

in Id.

"Keller \& Bernstein, supra note 32, at 418 n.12.

in J. Eugene Salomon, Jr., Note, The Right of Publicity Run Riot: The Case for a Federal Statute, 60 S. Cal. L. Rev. 1179, 1205 (1987). 
right of publicity is a race to the top or bottom remains unanswered. Even if the right of publicity is judged to be unquestionably beneficial, the ideal form of that right remains uncertain. Federalism can function here as it does in corporate law, to help determine the best form of the right. Alternatively, different states may experiment with various formulations of the rule and enact those that best meet their specific needs. This Part also addresses potential criticisms of the application of federalism arguments to the right of publicity, most notably the contention that states would never compete for celebrities as they do for corporations. Finally, this Part makes the doctrinal point that in general, our system allows the states to define property rights. The ultimate conclusion is that there are too many unresolved questions about the most advisable features of a right of publicity for it to be enshrined in federal law yet.

Economist proponents of federalism and their critics implicitly agree that there is a right answer. If competition produces the most efficient result, it is described as a race to the top, a qualitative good. If competition for corporate charters and industry causes shareholders or the environment to lose out, then it is a race to the bottom, which is by definition qualitatively bad. Professor Richard Revesz points out that these assumptions may be false: "If one beheves that competition among sellers of widgets is socially desirable, why is competition among sellers of location rights socially undesirable?" ${ }^{39}$

One reason that competition in the case of the environment could be undesirable flows from a public goods argument. If everyone benefits equally from clean air and water, individual states have a dismcentive to tax their citizens. They will not capture the full benefit of a reduction of air and water pollution, and they could simply free-ride off of the pollution-reduction actions of other states. Only a national government can tax the national class of beneficiaries.

However, a public goods argument for the federalization of the right of publicity is fairly weak. The right of publicity system cur-

${ }^{39}$ David L. Shapiro, Federalism: A Dialogue 81 (1995) (citing Richard Revesz, Rehabilitating Interstate Competition: Rethinking the "Race-to-the-Bottoin" Rationale for Federal Environmental Regulation, 67 N.Y.U. L. Rev. 1210, 1234 (1992)). 
rently in place has succeeded in extracting "user fees" from those who benefit from it, and paying those fees to the celebrities who are able to sue under state laws. For example, the reason one brand of perfume might cost more is because the consumer must subsidize the payment of publicity rights to Elizabeth Taylor, whose endorsement of the product is what led the consumer to select it. This higher cost is a "user fee." More fundamentally, it is not clear that celebrities are "pure" public goods where the entire nation benefits equally. In other words, before imposing a national "tax" by federalizing the right of publicity under a public goods rationale, there must be agreement that protection of people's riglit to control commercial exploitation of their personas grants a nationwide benefit that individual states are deterred from providing on their own.

In the right of publicity context, as perhaps in unany competitive contexts, the application of "race to the top" and "race to the bottom" language may prove unhelpful, since the question of which end is "up" remains unresolved. For a true believer in the necessity of protecting celebrities from exploitation in all cases, the race to the bottom would mean a situation where states allow corporations to trade on the publicity value of celebrities without compensating the performers (of course, federal trademark and false endorsement protections would limit this permissiveness), while a race to the top would maximize protection of rights in one's persona. For one who believes the danger lies in celebrities curtailing free speech and imposing fees that drive up the costs of products, the specter of states catering to celebrities at the expense of consumers makes that same scenario a race to the bottoin. ${ }^{41}$ The states have

* One could argue that celebrities' images are a public good that all must pay for in order to avoid free riding problems. A better reading of the argument is that images are impure public goods. Consumers who enjoy the image enough pay a user fee in the form of increased price, while those that do not enjoy it pay nothing. See Shapiro, supra note 39, at 82-83. An analogy between dilution of image and the unworkable nature of a piecemeal broadcast systein loses its bite where copyright and false endorsement protection continue to exist.

4 The fact that New York and California, two states with a high number of celebrities. have been leaders in the expansion of the right of publicity suggests that celebrities, in these states at least, are a powerful interest group. If one accepts public choice analysis and disapproves of the power of interest groups to gain concessions, another argument in favor of keeping the right of publicity state-determined emerges. Rather than the Madisonian view of the national government as a counter to 
not uniformly embraced the right of publicity, especially as a distinct property right. Given the various criticisms that can be leveled at such a right, ${ }^{42}$ and the current variations in its defimition, it seems premature to choose one side's value system over another's and enshrine it as the national rule.

In addition, beyond the simple binary of accepting or rejecting a right of publicity, there is another factor to consider: the optimal form a riglit of publicity should take. Currently state regimes vary greatly as to assignability, survivability, and protected features. Analogizing to the corporate context, the argument there is not whether states are racing to the top or bottom in their choice of whether or not to have corporate law: All states have corporate law. The argument that Delaware is the best state in which to incorporate because features such as a sophisticated judiciary and well-developed case law lead to a level of stockliolder protection optimal for wealth maximization finds an analogne in the right of publicity context: Federalism is important because through competition, the best form of right of publicity law can emerge.

One argument agaimst the competition justification for a statebased riglit of publicity is that states would never compete for celebrities the way they would for corporations. The choice of domicile for a celebrity is more likely to be driven by convenience, personal preference, and career concerns than by the perceived urgency of protecting one's image. It is therefore unlikely that a star would use his or her right of exit as quickly as a corporation might. Still, at least one judge has argued differently: "[I]t would be rational for the Tennessee courts to adopt a policy enhancing the continued growtli of Nashville and Memphis as centers for the lives and activities of music industry personalities." ${ }^{44}$ This comment of a New York federal appellate judge on the likely rulings of a Tennessee state court may prove maccurate, but it is noteworthy that

factionalism, public choice theory suggests that interest groups can gain more on the national scene. Id. at 80-81. Even if in the case of the right of publicity the opponents of the right on the state level are no less dispersed than they are on the national level, the federal system's inherent barrier of requiring separate action in all fifty states may be a useful counter to easy interest group access to the national government.

${ }^{42}$ See infra Part III.

${ }^{43}$ See supra notes 32-36 and accompanying text.

${ }^{4}$ Factors Etc. v. Pro Arts, 652 F.2d 278, 288 (2d Cir. 1981) (Mansfield, J., dissenting). 
this judge recognizes the protection of celebrities in order to encourage a state entertainment industry as a potential and legitimate state goal.

Even without the direct vying for celebrities which classic competition analysis would imply, federalism is also premised on the notion that state experimentation is beneficial to the nation as a whole. This argument assumes "that a well-conceived and smoothly operating federal system is one in which policy emerges as part of a process and from the interplay of a multiplicity of sources." The Brandeis version of this argument ${ }^{46}$ conceives of the states as laboratories that experiment and ultimately discover the best national solution. ${ }^{17}$ In the right of publicity context, presumably the "best" would mean the ideal balance of speech protection and celebrity protection which does not raise the price of marketed goods "too much." An alternate version of federalism allows different strokes for different states, recognizing that different constituencies and situations might entail different solutions for the same policy problem. ${ }^{19}$ Given the right of pubhicity's character as an informational property right, and the problems of conflict of laws that will be discussed later, the Brandeis model seems like the best one. Since no consensus has yet emerged on what inakes the best right of publicity system, however, this model would counsel keeping the issue firmly in state hands for now.

Finally, there is the elementary proposition that it is the states that traditionally define property rights in our system of government. This observation is so basic that it is not often articulated $\mathrm{m}$ law review articles or cases. Board of Regents of State Colleges $v$.

\footnotetext{
* Shapiro, supra note 39 , at 77.

t See New State Ice Co. v. Liebmann, 285 U.S. 262, 311 (1932) (Brandeis, J., dissenting).

${ }^{17}$ Shapiro, supra note 39 , at 85 .

* A counterargument is that there is no such thing as "too high" a price to pay for celebrity. If the price a celebrity demands is too high, producers will turn to another celebrity. Zimmerman, at least, would respond to this that property rights should only be recognized when they are value-creating, and there is a presumption against property rights in information and image. Zimmerman, supra note 3 , at $81-82$. This relates to the Demset $z$ theory that property rights arise when it becomes efficient to have them. Consistent with this theory, Zimmerman argues that there is no need to create a property right in a celebrity's image because celebrity will be cultivated even without it. Id. at 77.

"Shapiro. supra note 39 , at 85 .
} 
Roth $^{50}$ treats it as a given: "Property interests, of course, are not created by the Constitution. Rather they are created and their dimensions are defined by existing rules or understandings that stem from an independent source such as state law." ${ }^{\text {s1 }}$ It is true that the federal government protects individual rights in takings cases, ${ }^{52}$ and the Constitution gives it the power to control intellectual property such as copyright. ${ }^{53}$ The Federal Communications Commission also provides federal regulation of broadcast media in cases where central regulation is needed $\mathrm{m}$ order for meaningful property rights to exist. But these are exceptions to a general rule of state dominion over the definition of property, a power that states will guard jealously in the current political climate emphasizing state sovereignty and control.

The nnain point is that there is no consensus on what level of protection celebrities should be afforded. There are justifications for the right of publicity and criticisms of those justifications. Until a more general agreement is reached, it would be premature to enshrine one version of the right as national law. Instead, we should allow the states to experiment with different right of publicity schemes. Even assuming that we might later decide to bestow national recognition on a property right in personas, we should still wait for a broader consensus to emerge.

\section{JUSTIFICATIONS FOR THE RIGHT OF PUBLICITY AND POTENTIAL CRITICISMS}

This Part presents common justifications for the right of publicity and counterarguments to those justifications. The justifications include the theories of labor, unjust enrichment, personal autonoiny, incentive, efficiency, and consuner confusion. The aim of this Part is to show that states have good reasons to adopt the right, and sound reasons to reject it or hinit it, as well. Not only must each state decide whether, on the whole, the arguments for or against the right of publicity are nore persuasive; each state must

so 408 U.S. 564 (1972).

51 Id. at 577.

${ }^{52}$ See, e.g., Lucas v. S.C. Coastal Council, 505 U.S. 1003 (1992).

${ }^{53}$ U.S. Const. art. I, § 8, cl. 8. 
also decide how robust or weak to make the right, and these arguments inform that decision.

After the Haelen Laboratories v. Topps Chewing $\mathrm{Gum}^{54}$ decision, Professor Melville Nimmer publislied the influential article, "The Right of Publicity." In it, lie argued that celebrities' investment of time, skill, money, and effort combined to inake their names and likenesses economically valuable to promoters. ${ }^{56}$ Professor Nimmer proposed a labor theory of the right of pubhicity: A celebrity, like anyone else wlio labors to create soinething, deserves to profit from his or her labors. ${ }^{57}$ The Zacchini v. ScrippsHoward Broadcasting $\mathrm{Co}^{58}$ Court endorsed this justification for the right of publicity. ${ }^{59}$ States can justify publicity laws that encourage entertamers and creative artists with the same rationale of encouraging individual creative effort that proinpted patent and copyright laws.

There are several criticisms that can be levied at this labor theory of the right of publicity, however. Some critics argue that fortuity, more than talent or expenditure of effort, causes celebrity." "Critics of the labor/property rationale also note that a celebrity's fame seldom results solely from his or her labor. Instead, the pubhic-through its reaction to the supposed 'laborer'serves as the ultimate determinant of whether the would-be celebrity becomes a celebrity in fact." ${ }^{62}$ This tlieory might also suggest that in the White v. Samsung Electronics America, Inc. ${ }^{63}$ case it should have been Merv Griffin Productions, the labor-expendimg purveyor of the Wheel of Fortune game show, and not Vanna White, who had a cause of action in a right of publicity case.

A related argument by celebrities' proponents is that defendants who capitalize on the image of a celebrity to sell a product are nn-

202 F.2d 866 (2d Cir. 1953).

"Melville Nimmer, The Right of Publicity, 19 Law \& Contemp. Probs. 203 (1954).

" ld. at 216.

"ld.

433 U.S. 562 (1977).

"Id. at 576-77.

*Id.

"Langvardt, supra note 22, at 337. Langvardt uses Brian "Kato" Kaelin as perliaps the ultimate example. See id. at 337 n.50.

a. Id. at 337-38.

o2 971 F.2d 1395 (9tlı Cir. 1992). 
justly enriching themselves, free-riding on the work of others. ${ }^{64}$ However, this justification assumes an entitlement. ${ }^{65}$ It is not a foregone conclusion that the creation of something valuable presupposes a property right. ${ }^{66}$ Creating private rights is a departure from the norm that should be reserved for important social goals, as in the case of copyright. ${ }^{67}$ Even if audiences are not the ones who create the publicity value, celebrities' images still require development and marketmg. The purveyor of the image is a necessary, though not sufficient, part of the creative process-a co-creator. ${ }^{69}$

An economic argument against the unjust enrichunent justification for the right of publicity also exists. The defendants are the public's proxy, and if no one controls celebrities' images, then the consumer pays less. If the "free-riding" seller is deriving too much profit from using the image, then competition will correct the problem when anotlier seller steps in to benefit from the use of the same image. ${ }^{69}$ The publicity value may be a surplus, "the economic space between the most a consumer would be willing to pay and the minimum price for which the manufacturer is willing to sell."70 Given the choice of distributing the surplus to consumers or to celebrities, the traditional antitrust and intellectual property solution is to give it to consumers. ${ }^{71}$ To give it to the celebrities when there are no proven economic benefits to doing so is bad policy. ${ }^{72}$

Another justification offered is that of protecting personal autonomy. ${ }^{73}$ The intuition is that a person's identity is their own,

ब4 Richard Cameron Cray, Comment, Choice of Law in Right of Publicity, 31 UCLA

L. Rev. 640, 642-43 nn.23-24 (1984).

${ }^{65}$ Zimmerman, supra note 3, at 78.

${ }^{66}$ Rochelle Cooper Dreyfuss, We Are Symbols and Inhabit Symbols, So Should We

Be Paying Rent? Deconstructimg the Lanham Act and Rights of Publicity, 20 Colum.-

VLA J.L. \& Arts 123, 142 (1996).

${ }^{67}$ Id. at 142-43.

6s Id. at 141.

${ }^{69} \mathrm{Id}$.

${ }^{70}$ Zimmerman, supra note 3, at 80-81.

${ }^{11}$ Id.

72 Id. at 81 . "Unless shifting more financial rewards to the famous convincingly gets us a more desirable level of celebrity, or a product that we want and would not otherwise have, publicity claimants do not have a legally compelling claim for a dollar more of the surplus value associated with their fame." Id. at 81-82.

${ }^{73}$ For a discussion of the distinction between the labor justification and that of personal autonomy, presented as a distinction between Lockean and Kantian philosophy, see Haemmerli, supra note 1. 
and they should control it and choose when and how it is exploited. ${ }^{74}$ The choice of whether or not to exploit public recognition is an assertion of personality, one whicl affects the image the public sees." For example, the singer Tom Waits has a "no commercial" policy and was able to win an award of almost $\$ 2.5$ million in a soundalike suit in a case where Frito-Lay hired a singer who closely imitated Waits's voice. ${ }^{76}$ Waits feared that his fans would believe he had sold out." Still, this justification fails to account for the survivability feature of the right of publicity. After a celebrity's death, the personal autonoiny interest no longer exists. In addition, one could argue that, if personal autonomy is the interest we seek to protect, we should not permit the transfer or sale of publicity rights. Otlerwise a person would lose control over his or her own persona. ${ }^{78}$

The incentive rationale is that, without the protection of commercial use of their personas that the right of publicity affords celebrities, they will have a diminisled incentive to create, leading to the social harm of less creativity. ${ }^{79}$ Even advocates of this position, however, admit that many celebrities are not primarily motivated by the protection that publicity rights afford them. ${ }^{80}$ The right of pubhicity creates only a inarginal increase in incentives. The idea that the right of pubhicity affects the amount of celebrities' exertion more than tangentially is "einpirically dubious." $\$ 1$ Comparative law provides einpirical proof that it is particularly unlikely: "Proof of this [the falsity of the incentive rationale] can

${ }^{7}$ Keller \& Bernstein, supra note 32, at 416; see also Salomon, supra note 38, at 1186 (stating that concerns over personal autonomy provide a disincentive to create in states where there is no right to publicity).

"Salomon, supra note 38 , at 1189.

"Waits v. Frito-Lay, 978 F.2d 1093, 1096 (9th Cir. 1992).

${ }^{77}$ Id. at 1104.

"* One of Salomon's arguments for having a right of publicity is to help struggling young musicians who can depend on this right early on in their careers-answering objections to the incentive rationale that will be discussed below with the argument that publicity rights have real value early on in a career. Salomon, supra note 38 , at 1185. But if these rights do have value, then it seems clear that agents who are promoting the performers, or whoever else may be financing them, will demand that their clients assign their rights away as a condition of employment. Giving soneone a property right does not guarantee that they will be able to profit from it.

${ }^{74}$ Id. at $1185-86$.

*Id. at 1186 n.49.

« Zimmerman, supra note 3, at 77. 
be found in the fact that many countries-Great Britain, for example-produce quite a healthy crop of persons committed to becoming celebrities without the help of a legally recognized publicity right." ${ }^{\text {22 }}$ It is also true that, as a rule, "the costs of creating a persona are recaptured through the activity with which the purveyor is primarily associated., ${ }^{, 33}$ Consider the incentives of fame itself, and the money that usually accompanies it in the form of record sales, movie deals, endorsements, and other revenue streams more closely tied to whatever makes a person a celebrity. Given these incentives, it seems ludicrous to imagine that entertainers will be dissuaded from pursuing their artistic aspirations because of the potential of a loss of control over the marketing of that small area of persona that the right of publicity, but not tlie Copyright Act or Lanham Act, covers. ${ }^{84}$ Still, the incentive argument appears both in Zacchini and in Professor Nimmer's article ${ }^{85}$ It could even be that the right creates the wrong incentives. Celebrities no longer have to improve their image by excelling in their field of expertise, but can rather rest on their laurels, making money off their past acts. For example, one cominentator suggests that the 1995 baseball and hockey strikes were made possible by the financial freedom that merchandising revenue afforded players. ${ }^{86}$ To the extent that false endorseinent and consumer confusion failed to protect these celebrities from cominercial exploitation, this surplus income derives from the right of publicity.

An efficiency justification for the right of publicity posits that granting exclusive property rights is the most efficient way to allocate scarce resources. ${ }^{87}$ This "induces the advertiser with the highest-valued use to purchase the right to use the identity at the market price." $\$ 8$ Professor Diane Leenheer Zimmerman decries lawmakers' and creators' instinct to claim property rights in infor-

s2 Diane Leenheer Zimmerman, Fitting Publicity Rights Into Intellectual Property and Free Speech Theory: Sam, You Made the Pants Too Long!, 10 DePaul-LCA J. Art \& Ent. L. 283, 306 (2000).

${ }^{3}$ Dreyfuss, supra note 66 , at 144.

${ }^{84}$ As will be seen, causes of action like false endorsement may also help protect celebrities' rights.

${ }^{85}$ Zimmerman, supra note 3 , at 48 n.39, 49.

${ }^{86}$ Dreyfuss, supra note 66 , at 145.

${ }^{87}$ Keller \& Bernstein, supra note 32, at 417.

Id. (citation omitted). 
mation and divide up the "informational commons." sources in question here are only scarce if we assume that overuse that will deplete the resource is possible. The counterargument is that if a celebrity cannot control the use of his or her image and guarantee its exclusivity to advertisers, the image is worth less. This is probably the most convincing argument for the right yet articulated, but if image dilution is not a problem, it loses force. For example, the Easter Bunny, Santa Claus, and Impressiomist paintings are examples of cultural capital that do not appear to have lost too much resonance, despite widespread circulation. ${ }^{91}$ In addition, even without the right of publicity, celebrities would still be able to bring false endorsement claims covering their names and likenesses in their lifetime, which should obviate much of the dilution problem.

Consumer confusion is at issue in the right of publicity context, as it is in the trademark context. ${ }^{92}$ But it is not a prerequisite for a right of publicity cause of action. ${ }^{93}$ All one must prove is identifiability, which is easily accomplished since it is generally in a defendant's interest to make tlie identity of the celebrity obvious. ${ }^{94}$ Mere intent to trade on the goodwill of the plaintiff is enough. ${ }^{95}$ To a degree, this aspect of the riglit of publicity has already been federalized. Section 43(a) of the Lanham Act has been construed to protect personal images. Using the false endorsement criteria of Section 43(a) would preserve several elements of the current right of publicity protection, as it exists in the states that recognize it, including use of name, likeness, or identity in a commercial setting and lack of consent. ${ }^{97} \mathrm{~A}$ false endorsement claim, however, would necessitate an additional requirement not typically found in right of publicity law: "proof of the hikehhood of consumer confusion concerning whetler the plaintiff endorses the defendant's goods or

* Zimmerman, supra note 3, at 51-52.

* See Salomon, supra note 38, at 1193-94.

"Dreyfuss, supra note 66, at 141.

${ }^{92}$ Richard S. Robinson, Preemption, the Right of Pubhicity, and a New Federal Statute, 16 Cardozo Arts \& Ent. L.J. 183, 191 (1998).

${ }^{42}$ Id. at 192.

Keller \& Bernstein, supra note 32, at 433-34.

"Id. at 434.

* Dreyfuss, supra note 66, at 126 .

${ }^{97}$ Langvardt, supra note 22, at 354. 
services or is otherwise affiliated with the defendant."98 This additional sorter would exclude White-like cases, where consumers are not hikely to suspect that a celebrity has endorsed the product being sold. It would probably have the practical effect of granting a parody exception to the right of pubhicity.

This Part has discussed the common justifications for the right of publicity and counterarguments against them. But this does not mean that federalism's laboratory will have to conclude its experiments by rendering a yes-or-no judgment on the right of publicity. On the contrary, the fact that half of the states have adopted some form of the right ineans that it is likely here to stay. Takings law makes clear that rights, once vested, are hard to take away. The question remains: If a state decides to recognize the right of publicity, what should the contours of the right be? States should consider the justifications for having the right and their counterarguments when deciding how expansive or narrow to make the right. If the rationale accepted is one of personal autonomy, then the right should terminate upon death, when the individual autonomy no longer needs protection. If the justification is incentivebased, states may want to look at the decreasing marginal utility of extending the right for decades after a celebrity's death. If a state embraces the labor theory, then perhaps the fruit of the celebrity's work should continue in perpetuity, just like that of a fanily farm or family business.

California has a state law regime that many think is expansive, as exemplified by White v. Samsung Electronics America. ${ }^{99}$ There, a robot dressed witlı a blonde wig, evening gown, and jewelry was deemed to infringe on Vanna White's right of publicity. ${ }^{100}$ One scholar, Professor Arlen W. Langvardt, rejects the idea that the Wheel of Fortune set pictured in the advertisenent was a personal attribute of Ms. White. ${ }^{101}$ If anyone should sue, he argues, it should be the copyright holder in the show..$^{102}$ One of the dangers he sees in the White decision is the prospect of an "Orwellian" world where attenuated reference is enough to trigger liability. Another

\footnotetext{
${ }^{98}$ Id.

99971 F.2d 1395 (9th Cir. 1992).

${ }^{100}$ Id. at 1399.

${ }^{10 t}$ Langvardt, supra note 22, at 419.

${ }^{102}$ Id. at $423-24$.
} 
danger is that it creates a property right without limits. ${ }^{103}$ This enhances copyright conflicts and threatens freedom of expression. Potential defendants may also have no notice that they are infringing. Professor Langvardt suggests instead that the right be limited to personal and unique attributes, ${ }^{104}$ that the law require proof of the likelihood of confusion,${ }^{105}$ and that there be more of an effort to accommodate First Amendment interests. ${ }^{106}$

\section{REASONS FOR FEDERALIZING THE RIGHT OF PUbLICITY}

Some of the arguments for federalizing the right of publicity flow naturally from acceptance of the justifications set out above. For example, if one accepts that the economic and personhood concerns addressed by the right of publicity outweigh the expressive value of commercial speecl, one would endorse federalizing right of publicity protection ${ }^{107}$ A First Amendment exception could then protect image use im news and entertaimment. ${ }^{108}$

A separate issue is the current intertwining of state and federal law, and the hazy boundary between the two that potential hitigants must traverse. The practical version of this story is that intelligent plaintiffs will usually include federal claims in their causes of action, such as claims based on Section 43(a) of the Lanham Act, ${ }^{109}$ so that most cases are heard before federal courts. This explains the fact that in the right of publicity area, much of the "state law" that we have actually stems from federal courts hypothesizing about how a state court would rule.

There are potential conflicts between the right of publicity, federal copyright law, and the Lanham Act. The question of preemption looms large. Section 301 of the Copyright Act preempts state-created rights that are equivalent to those created by the Copyright Act and that cover the saine subject inatter as the

ini Id. at 418-22.

in Id. at $440-43$.

i" Id. at 443-47. Langvardt argues that not requiring consumer confusion is a mistake because it eliminates the possibility of commercial parody. Id. at 353.

${ }^{1 \text { ik }}$ Id. at 447-51.

${ }^{1 \cdots *}$ See Salomon, supra note 38, at 1194.

in Id.

Symposium, supra note 1, at 213. 
Act. ${ }^{110}$ While some commentators believe that the Act preempts the right of publicity, others disagree, either because a persona is not a writing or because the right protects an interest different from copyright. ${ }^{111}$

The Lanham Act is another area of potential conflict for right of publicity causes of action. A federal right of publicity may be required if plaintiffs cannot rely on the Lanliam Act for full protection. The Act requires the imvolvement of goods and services, an effect on interstate commerce, and false designation of origin or description. ${ }^{12}$ The Act also requires potential deception, so there are cases protected under the right of publicity that the Lanham Act would not protect. ${ }^{113}$

The chief attraction of a uniform federal law is that it would solve the formidable problems of uncertainty that botl plaintiffs and defendants face in this arena. It would reduce the costs to potential defendants, who would otherwise liave to investigate the laws of each state in which they wished to advertise. ${ }^{114}$ It would also reduce the confusion occasioned by state variations as to whether the commercial value of the persona must be exercised lest it be deemed waived. ${ }^{115}$ As we will see, the uncertainty occasioned by choice of forum and choice of law is also a major concern in these cases. ${ }^{116}$ The burden of nationwide enforcement is considerable if state court remedies are limited to in-state infringement. ${ }^{117}$ Thus, a federal right of publicity would give celebrities the incentive to create by lowering the cost of enforcement related to protecting one's image. ${ }^{118}$

It is clear, lowever, that these arguments are most persuasive to those who already have the faith. Those who refuse to accept the right of publicity as an unmitigated, unquestionable blessing can rely on the Lanham Act and Copyright Act to protect the most egregious, false-endorsement sort of behavior, and conflicts with

\footnotetext{
${ }^{110} 17$ U.S.C. § 301 (1994).

${ }^{11}$ Salomon, supra note 38, at 1187.

11215 U.S.C. \& 1125 (1994).

${ }^{113}$ Salomon, supra note 38, at 1196.

${ }^{114} \mathrm{Id}$. at 1181.

${ }^{115}$ Id. at 1190.

${ }^{116}$ Id. at 1180.

${ }^{117}$ Id.

${ }^{118}$ Id. at 1185.
} 
these federal statutes no longer pose such a problem. One might object that, given the enforcement and choice of law difficulties, limiting plaintiffs to state causes of action diminishes the bite of the right of publicity - but there is no requirement that national law be changed to maximize state causes of action. Property is traditionally a realm reserved to the states, and the state-varied property regime of community property has existed for centuries.

The fact that the law of the right of publicity is not clearly settled does not lead inexorably to the conclusion that the federal government must step in to resolve the disputed issues. An equally plausible reading of the current situation is that the states are still trying to work out the proper contours of a relatively young right (by property law standards, at least), and the federal government should wait until state law has solidified. Most states have addressed cases of commercial appropriation of identity only rarely, if at all. ${ }^{119}$ Examples are Alaska, Minnesota, and New Hampshire. ${ }^{120}$ Although twenty-seven states have recognized a form of the right of publicity, "only about a dozen have taken unanıbiguous steps to create a true property right."121

\section{The Choice of LAW PROBLEM}

The boundaries of right of publicity law are unclear in many states. One case describes the law in this area as resembling "a haystack in a hurricane." ${ }^{22}$ Compounding the problem is the lack of sensitivity in inany cases to choice of law issues. Even if many states have an interest in the outcome of a decision, courts are often inclined to apply their own state's law mechamically. ${ }^{123}$

One exanıle of the coniphications choice of law can pose is Groucho Marx Productions v. Day and Night Co. ${ }^{124}$ This case imvolved a Broadway musical called $A$ Day in Hollywood, $A$ Night in the Ukraine and three performers who reproduced the comic style

${ }^{114}$ Zimmerman, supra note 3 , at 40 .

12i) Id. at 40 n.17.

${ }^{12}$ Id. at 41. Zimmerman only lists California, Florida, Georgia, Indiana, Kentucky, Nevada, Oklahoma, Tennessee, and Texas, however. Id. at 41 n.19.

1: Cray, supra note 64, at 642 n.19 (citing Ettore v. Philco Television Broad. Corp., 229 F.2d 481. 485 (3d Cir. 1956)).

${ }^{123}$ Id. at 646.

124 689 F.2d 317 (2d Cir. 1982). 
of Groucho, Chico, and Harpo Marx. The District Court for the Southern District of New York ruled that New York law governed, since the play ran longest there, and the Marx Brothers characters were originally developed in New York. ${ }^{125}$ The Second Circuit reversed, ruling that a New York court would apply California law, since the Marx Brothers were California residents at their deaths, and the plaintiff was a California corporation. ${ }^{126}$ Further, before his death Groucho assigned his right of publicity to the plaintiff with a contract executed in California. ${ }^{127}$ Finally, Chico's estate did the same eighteen years after his death. ${ }^{128}$ Cases in which a trial court is reversed on appeal for failing to consider choice of law constraints, or for ruling incorrectly on thein, are fairly common. ${ }^{129}$

The scope of permissible power that a state has over action in other states is another side of the choice of law issue. California, Kentucky, Florida, Oklahoma, Utah, and Virginia statutes do not require that the exploited individual or the defendant reside in the state, or that the commercial use take place in the state..$^{130}$ The defendant can theoretically be brought in with a long-arn statute by selling products or showing ads within the state. Defendants have no way to predict when they will be liable. If courts fail to apply conventional choice of law analysis, then the "race to the bottom" may already be over; any celebrity could theoretically sue under these statutes. This has not proven to be the case, however. The choice of law decisions, at least thus far, seem to be counteracting plaintiffs' efforts to use certaim states to sue when there is no real

${ }^{125}$ Id. at 319.

${ }^{126}$ Id. at 320.

127 Id.

${ }^{128}$ Cray, supra note 64, at 650 (citing Groucho Marx Prods., 689 F.2d at 320).

${ }^{129}$ See Allison v. Vintage Sports Plaques, 136 F.3d 1443, 1445 n.6, 1446-47 (11th Cir. 1998) (affirming the trial court's ruling, but noting that the district court did not adequately address the choice of law issue); Saloinon, supra note 38, at 1182 (citing Southeast Bank N.A. v. Lawrence, 489 N.E.2d 744 (N.Y. 1985), in which New York's highest court ruled that a Manhattan theater called the "Tennessee Williams" was governed by Florida law although both parties and the lower courts thought New York law controlled); see also Factors Etc. v. Pro Arts, 652 F.2d 278 (2d Cir. 1981) (holding that Tennessee law, not New York law, governed in a case determining whether a corporation formed by Elvis Presley had exclusive rights to merchandize his name and likeness after his death, when Tennessee was both where Presley was doiniciled and where the corporation was incorporated). For a list of cases with choice of law analyses, see Cray, supra note $64,643 \mathrm{n} .28$.

${ }^{130}$ Salomon, supra note 38 , at $1180-81$. 
connection to the forum. For example, in a recent case, a federal court denied a claim under California law because the claimant sued on behalf of Princess Diana, who, at the time of her death, was domiciled in Britain, which does not recognize the right of publicity. ${ }^{13}$

The question of renedy is another potential stumbling block. Plaintiffs might have to bring fifty-one separate suits in order to prevent commercial exploitation of their personas nationwide. Alternatively, damages could be reduced to those within the state declaring judgment. Or perhaps defendants could persuade a court to limit damages to the amount available in states where the plaintiff could win. ${ }^{132}$ This last possibility actually seems the most fair, but it would imvolve the burdensoine examination of the law of fifty states. Still, this type of remedy was imposed when Johnny Carson sued a portable toilet company. He obtained a nationwide injunction prohibiting the company froin using the name "Here's Johnny!," but the defendant could eliminate states if it could show that the sale was legal there. ${ }^{133}$

Two alternative solutions to the choice of law problem may be workable. The first conres from Richard Cameron Cray, who advocates federal legislation to make right of publicity law uniforn, but in the alternative, endorses suit in the place of greatest infringement as the next best solution. ${ }^{134}$

To some extent, the use of any smgle state's law to govern a controversy with sigmificant multistate consequences will be inherently arbitrary. Nonetheless, where one can discern a state of greatest infringement, applying that state's law to the right of publicity controversy will be less arbitrary than applying law selected through choice of law factors that do not focus upon the situs of the alleged injury.

In federalism terms, this would allow states to vary the protection celebrities receive within their borders. It might well be in a state's interest to encourage in-state individual enterprise and creativity by vigorously enforcing celebrities' rights of publicity.

\footnotetext{
"Cairns v. Franklin Mint Co., 24 F. Supp. $2 d$ 1013, 1029 (C.D. Cal. 1998).

12 Salomon, supra note 38 , at 1184.

17 Keller \& Bernstein, supra note 32, at 434.

14 Cray, supra note 64, at 662 .

${ }^{13} \mathrm{ld}$. at 663.
} 
The second possible solution that courts have used is the domicile factor, on the basis that states are more likely to compensate their own residents than foreigners injured within their borders. ${ }^{136}$ This approach may be criticized as artificial, given the intangible nature of the property in question here. ${ }^{137}$ But if a state makes the right of publicity a property right, the next logical step is to try to delimit it geographically and use its situs as a guide in choice of law questions. Also problematic is the fact that this approach is more akin to privacy actions, where the cause of action is necessarily related to the celebrity; in right of publicity, on the other hand, it may be assigned away or survive the death of the public figure. ${ }^{138}$ The attraction of this approach is that it would allow states to compete with each other to attract celebrities to reside within their borders, if it is worth their while to do so, and to custom-tailor regimes inost likely to ineet their constituents' needs. The downside to this is that it would allow celebrities to shop for the inost protection, or to strike a balance between other factors determining domicile and degree of publicity protection. Of course, this might not be a downside at all.

One obvious objection to this argument is that states simply will not compete for celebrity domicile. The immediate response is that they might; tax revenues aside, having a sizable celebrity population might increase tourism or even general positive exposure for a state like Rhode Island. A deeper response is that it does not niatter if states do not compete on the levels of right of publicity they offer. If celebrity domicile is a matter of imdifference, then there will be no competition, and states will select other areas in which to compete. The current variation in state law, however, suggests that soine competition might, in fact, exist. In Telmessee, for example, at least one court has suggested that states take this incentive seriously. "[I]t would be rational for the Tennessee courts to adopt a policy enhancing the continued growth of Nashville and Memphis

${ }^{136}$ Id. at 656 n.123 (citing Motschenbacher v. R.J. Reynolds Tobacco Co., 498 F.2d 821 (9th Cir. 1974)).

137 Id. at 655.

${ }^{138}$ Id. 
as centers for the lives and activities of music industry personalities." "134

Cray suggests that the problems of a multistate publicity action can be solved by adopting a strategy similar to that applied to multistate defamation and privacy actions. ${ }^{140}$ "Over the years, practical necessity prompted widespread adoption of the rule that only a single cause of action arose from multistate publication, a cause of action governed by the law of one state."141 Some states use the law of the plaintiff's domicile in such cases. ${ }^{142}$

This choice of law discussion indicates that the problem is not insurmountable. If courts treat the right as traditional property, they can use the state of domicile of the celebrity. If they wish to take into account its more fluid status with regard to place, they can choose the place of greatest infringement. Either rule is predictable and permits states to fashion their own policies. Choosing the state of domicile may even drive states to coinpete with each other for celebrity residency, as federalism literature suggests they do for bank charters and corporate charters.

\section{Community Property: A CASE Study}

The community property system in this country derives from the Spanish legal tradition. ${ }^{143}$ Nine states (Arizona, California, Idaho, Louisiana, Nevada, New Mexico, Texas, Washington, and Wisconsin) currently have community property regimes, but earlier, when federal tax laws offered community property a beneficial incomesplitting effect, several common law states converted their property regimes to community property, later reverting back to separate property when the tax laws were changed. ${ }^{144}$ The existence of this second, robust property system found in a substantial minority of states is an example of the feasibility of having property laws that vary significantly from state to state. The fact that some states have

${ }^{134}$ Factors Etc. v. Pro Arts, 652 F.2d 278, 288 (2d Cir. 1981) (Mansfield, J., dissenting).

1*) Cray, supra note 64, at 665-66.

148 Id. at 666.

14 Id. at 666 n.187.

${ }^{14}$ Lawrence W. Waggoner et. al., Family Property Law: Cases And Materials On Wills, Trusts, and Future Interests 518 (2d ed. 1997).

14 Id. at 519. 
switched back and forth and that Wisconsin only adopted community property in 1986 suggests that property law is a legitimate area in which states can experiment, and perhaps compete.

Of course, conflict of law questions arise as couples move between common law and community property states. Three general conflict of law principles tend to control: The law of domicile at the time of acquisition determines ownership; moving or changing domicile does not change a person's legal interest in the property; and, finally, the law of the state of donicile at death governs the disposition of the property. ${ }^{145}$

There is one intriguing point miplicit in drawing an analogy between the right of publicity and community property, one that gets at the heart of characterizing the right as property at all. It is clear that personal property acquired in a non-community-property state camot be converted into community property by taking it into a community property state. ${ }^{146} \mathrm{~A}$ statute so providing would be unconstitutional, a breach of the Privileges and Immunities Clause and a taking without due process. ${ }^{147}$ If we determine a publicity rights cause of action based on the state of domicile, and the celebrity in changing domicile lost her publicity rights, would this be a taking $?^{148}$ Rights once vested are not disturbed. ${ }^{149}$ But when does a right of publicity vest? Is it when a celebrity reaches some quantifiable level of faune? Is it when she gets her first "big break?" This seems to inake rights turn on fortuity of place where fame developed, but the alternative is to recognize a property right that can change froin state to state.

Given the fact that the characterization of the right of publicity was done for expediency, to distinguish it from a privacy action, but is now recognized as a legitimate free-standing right, a question

${ }^{145}$ Hrant Norsigian, Note: Community Property and the Problem of Migration, 66 Wash. U. L.Q. 773, 777-78 (1988).

${ }^{146} 15$ A Am. Jur. 2d Community Property $\$ 17$ (2000).

${ }^{147} \mathrm{Id}$.

${ }^{145}$ Alternatively, if the choice of law rule applied is the state of greatest infringement rule, a property right will not vest and disappear according to changes in domicile, but according to the law of the state of greatest infringement. This is a perfectly good solution, but it does not offer the same opportumities to explore the nature of the property involved in the right of publicity.

${ }^{149}$ Friedrich K. Juenger, Marital Property and the Conflict of Laws: A Tale of Two Countries, 81 Colum. L. Rev. 1061, 1078 (1981). 
worth asking is: Should we continue to treat publicity rights as property at all? On the other hand, how could states that have recognized the riglit of publicity as a property right ever go back? It would seem impossible to take what appears to be a vested right away. But states could question how mucli social value there is in the power to assign this riglit or in having it survive death by one hundred years. The laboratories of the states afford a chance to work out liow to create a proper balance between freedom of speecli concerns and the goal of protecting the use of one's identity. No clear consensus as to the ideal balance lias arisen yet.

\section{CONCLUSION}

The existence of a community property system demonstrates that all fifty states need not liave uniform property regimes. Federalism's promise of slowly working out a problem by tinkering with variations until a workable model emerges is one that is relevant even in today's rapidly changing world of media and image exploitation. Dot-cons age notwithstanding, property remains an area of the law traditionally dommated by the states and slow to cliange. Given the right of publicity's debatable labor and incentive justifications, it is wisest to avoid enshrining on the federal level a inodel of persona protection tliat imight cement into an unwieldy and oppressive regime.

In light of recent developments in intellectual property and the Internet, the right of publicity tells us a story familiar in the law. The increasing use of the nuarketing of public figures' personas, a relatively new developinent, led to the rethinking of rights of privacy. The earlier legal protection no longer seemed adequate to protect decidedly public figures. The solution, granting property rights in the 1narketing of one's persona, gave celebrities power over their images, but that power was limited by state law and choice of law provisions. Federalism's best argument against a federal right of publicity is that property rights are state-created rights, and these rights of publicity are relatively young in the property law context. Calcifying tlient in federal law would be preinature. 
*** $*$ 